Review

\title{
Focus on the Chinese revolution of catalysis based on catalytic solutions for the vital demands of society and economy
}

\author{
Yangdong Wang a, Jing Shi a, Zhonghao Jin a , Zaiku Xie b,* \\ a State Key Laboratory of Green Chemical Engineering and Industrial Catalysis, SINOPEC Shanghai Research Institute of Petrochemical Technology, \\ Shanghai 201208, China \\ b China Petroleum \& Chemical Corporation, Beijing 100027, China
}

\section{A R T I C L E I N F O}

\section{Article history:}

Received 31 January 2018

Accepted 22 February 2018

Published 5 July 2018

\section{Keywords:}

Catalysis

Industrialization

Hydrocarbon production

Green technology

Catalytic development

\section{A B S T R A C T}

Catalysis is one of the most cross-cutting technologies in the chemical industry, intensely influencing our daily society. Its practical application is closely related to the engineering disciplines. At present, the academic and industrial research on catalysis in our country has made great breakthroughs in fields like hydrocarbon production, oil-quality upgrading processes, green chemical engineering, and other energy and chemical users of catalysis. In this paper, we attempt to summarize the industrial catalysis achievements and present a discussion on the direction and the development strategy for catalysis, based on economic and social demands.

(C) 2018, Dalian Institute of Chemical Physics, Chinese Academy of Sciences. Published by Elsevier B.V. All rights reserved.

\section{Introduction}

Catalysis, a core technology with great influence on socio-economic development, is a interdisciplinary science that integrates chemistry, materials science, engineering and other disciplines. The key aspect of catalysis is its actual practical application. It is therefore closely related to the chemical engineering discipline. The application performance of the catalyst is the fundamental strength of catalysis, and its developmental trajectory not only promotes social and economic progress, but also changes the historical process of human beings. In the early 20th century, Mittasch's contribution to the efficient Fe-based catalyst for ammonia synthesis laid the foundations for the development of modern agriculture and solved the problem of human food consumption with the large-scale pro- motion of nitrogenous fertilizers [1]. By the 1960s, the invention of molecular-sieve catalysts for oil cracking led to a substantial increase in gasoline yield and octane number and provided the energy foundation for the vigorous development of the transportation industry and led to its fascinating revolution [2]. The invention of the Ziegler-Natta catalytic system allowed the high-pressure efficient polymerization of ethylene, propylene and butene to high molecular structures and promoted the large-scale production of synthetic materials. The development of the three-way Pt-Rh-Pd catalyst for the decomposition of hydrocarbons, $\mathrm{CO}$, and $\mathrm{NO}_{x}$ in automobile exhaust, harmful to the environment, into the harmless $\mathrm{N}_{2}$ and $\mathrm{O}_{2}$, greatly improved the environment $[3,4]$. These important progresses in catalysis have accelerated industrial and social changes. It can be said that the ubiquitous catalyst has played a major supporting role

\footnotetext{
* Corresponding author. Tel: +86-21-68462947; Fax: +86-21-68462283; E-mail: xzk@sinopec.com This work was supported by National Key Basic Research Program of China (2013CB934101, 2009CB623500), the National Natural Science Foundation of China (21433002, 21573046) and the National Key Research and Development Program of China (2016YFB0701100). DOI: 10.1016/S1872-2067(18)63051-7 | http://www.sciencedirect.com/science/journal/18722067 | Chin. J. Catal., Vol. 39, No. 7, July 2018
} 
in the development of human society.

After a several-generations' effort by Chinese scientists and engineers, China has made a number of important breakthroughs in the development of science and technology that, in recent years, involve catalysis. The 16th International Congress on Catalysis has been successfully organized by Cai Li et al. Several scientists, like Can Li, Xinhe Bao [5,6], among others, have been awarded honorary titles by international academic organizations. Zhang's [7,8] series results were evaluated as important progresses. At the same time, we have achieved vital industrialization in the fields of hydrocarbon production, oil-quality upgrading processes, green chemical engineering, and other fields of energy and chemical catalysis [9,10]. These results of world-class major catalytic industrialization have, to some degree, driven China's economic and social development.

However, many complex issues need to be addressed for further development in the complex field of catalysis. On the one hand, it is necessary to clearly understand the complex surface science and physicochemical phenomena related to catalytic reactions, and to integrate materials science and new methods of inorganic chemistry to design and prepare complex nano-structures of efficient catalyst materials. On the other hand, the catalyst should be mixed with a binder and then shaped, and the reaction kinetics and modulation of the catalytic processes are still not very clear for industrial applications. Both these aspects involve complex problems such as materials diversity, variability of catalytic materials, chemical process suitability, macroscopic preparation, magnification effects, and correlations between intrinsic and apparent properties. These complex issues and the requirements for catalytic development should be mutually supportive and reinforcing. However, from the perspective of industrial catalysis, the most attention should be paid to the capacity of the catalysis to solve or not important economic and social problems; that remains the mission of catalysis $[11,12]$.
This paper attempts to summarize the achievements of the industrial catalysis, and tries to present a discussion on the direction and the strategy for catalysis, based on economic and social demands.

\section{The advancement driven by catalysis}

With the rapid economic development of our country, the challenges caused by the lack of energy resources and by environmental degradation have become increasingly significant. Catalytic workers have carried out much fundamental research as well as industrial practices in the areas of hydrocarbon production from coal and methanol (MTO and MTX processes), oil-quality upgrading, green chemical industry, and many more $[13,14]$. Important progresses have been made. Fig. 1 presents the milestones of major industrial catalysis.

\subsection{The production of hydrocarbons from coal}

In our energy consumption structure, $90 \%$ corresponds to fossil fuels, $68.7 \%, 18 \%$ and $3.8 \%$ being from coal, oil, and natural gas, respectively. Given the abundant coal resources in China [15], the development of hydrocarbons production from coal is of special significance. As the 485th Xiangshan science conference pointed out, in our society the key focus has been changed from hydrocarbons processing to hydrocarbon synthesizing. The economy is the basic and the most critical necessity for a technology. The value of the methanol-to-olefin (MTO) technology lies not only in its economy, but also in the exploration of a new non-oil olefin production path. By diversifying the raw materials for olefin production, such route would affect the global energy map. It is estimated that, in the next five to ten years, olefin production from coal will reach about a quarter of the total olefin production, making a significant impact on the olefin industry [16-18].

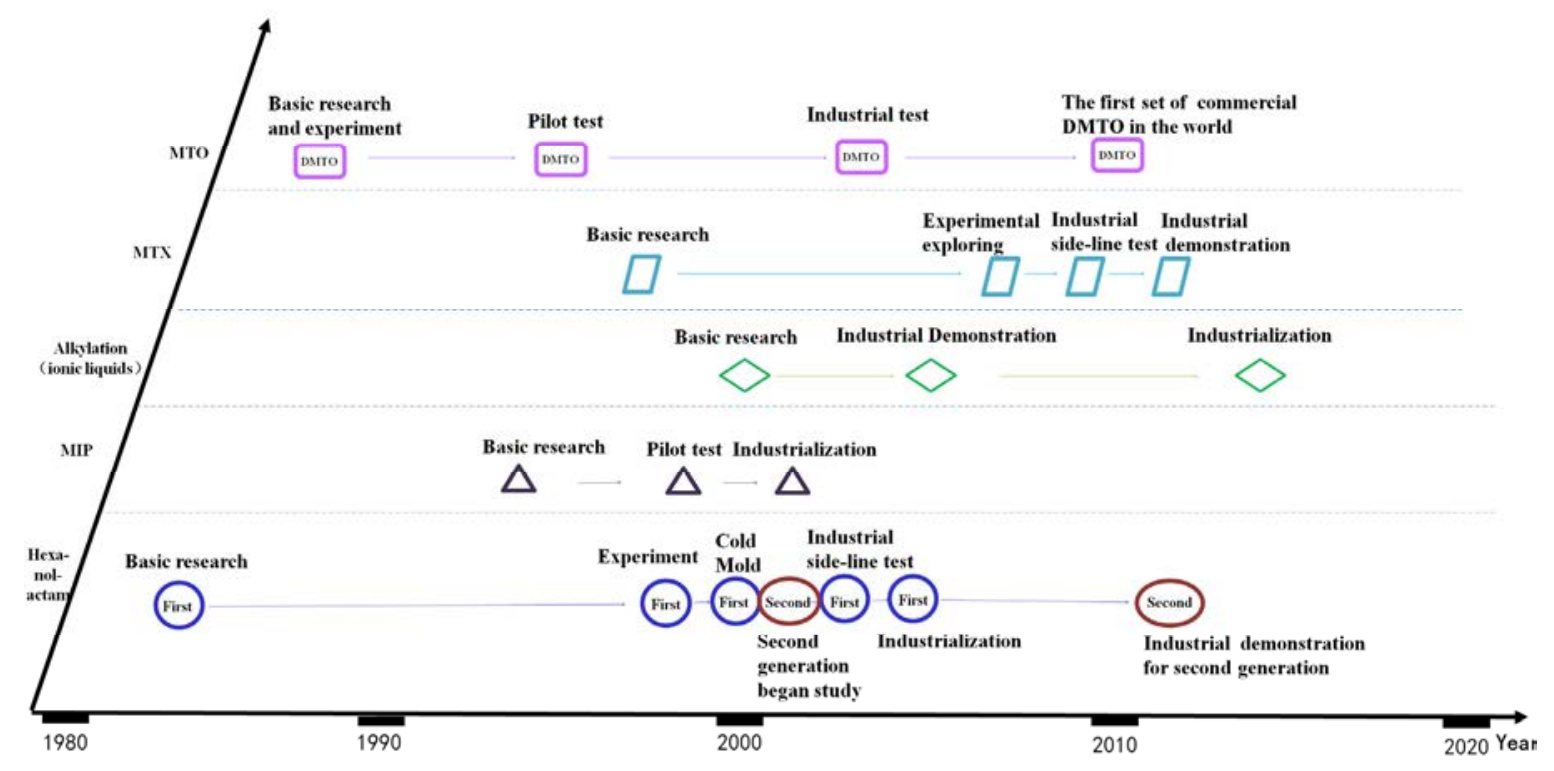

Fig. 1. The milestones of major industrial catalysis in China. 


\section{MTO}

The methanol conversion technology involves the zeolite synthesis, the mechanism of the elaboration reaction, the selective control in a complex reaction system, and other basic scientific issues. To find the solutions for these problems was very challenging [19-21]. In the late 1990s, Zhongmin Liu et al. from Dalian Institute of Chemical Physics (DICP) intensely engaged themselves on the basic and industrial research of the MTO technology. A series of problems in the preparation of the molecular sieve were solved. The performance of the catalyst was improved and the fluidized bed was successfully demonstrated. In the 21st century, they have organized many teams to tackle specific problems, such as the direct mechanism for the formation of the first $\mathrm{C}-\mathrm{C}$ bond in the MTH reaction, which was proposed and promoted the industrial test of the DMTO process, which led to its industrialization in 2010 [13,22]. In 2014, they were awarded the first prize for national technology invention. In 2000, the team of Sinopec began their research in this field and the combined technologies of SMTO and OCC (SMTO-OCC) were successfully industrialized in 2011 [23,24]. It has been proven that zeolites with nano-sheet morphology perform well in this reaction [25]. It should be said that the major breakthroughs in MTO technology benefits from the great demand of China's clean utilization of coal resources. The MTO technology has become the dominating chemical technology in this area, in the world.

Methanol to xylene (MTX)

The MTX technique has enabled the contact between petrochemical and coal chemical raw materials. The traditional disproportionation process of toluene was used in the preparation of xylene and benzene and the market price of the latter would directly affect the economy of the whole process. However, by introducing a methyl group through the MTX route, the product structure can be adjusted and the economy improved. There are many groups carrying out research on the shape-selective alkylation of methanol and toluene with the modified ZSM-5 zeolite, but the catalyst stability has been a difficult-to-cross barrier [26,27]. It is hard to avoid the self-reaction of methanol (MTO, MTG, etc.), which is an important cause for catalyst deactivation. The research team of Sinopec focused on the inhibition of the side reactions of methanol via an increased diffusion of the molecules [28]. According to recent literature [29], constructing hierarchical pores in the ZSM-5 zeolite catalyst or reducing its crystal size are of significance for converting the methanol feedstock into the para-methyl group of xylene. During 2012, after more than 10 years of continuous research, a 200000 ton/year petrochemical plant was built in Nanjing Yangzi. This was the first industrial unit of its type in the world and now the team has made great advances in the second generation of shape-selective technology. At the same time, great advances have also been made in the research and development of the DICP fluidized-bed process [30].

\subsection{Catalytic update technology for clean oil resources}

Based on the porous material and catalytic technology, our country has made great breakthroughs in the fluid catalytic cracking and deep catalytic cracking (DCC) technologies for poor-quality heavy crude oil, in the last century. The DCC was awarded the first prize for national technology invention and the ZRP zeolite developed by Mingyuan He et al. received China's top-ten scientific progresses award. In recent years, there have been significant breakthroughs in the oil-products quality upgrading such as the MIP process for maximizing iso-paraffins and ionic liquid alkylation [31].

MIP's "two reaction zones" concept

In the FCC process, due to the updated technology for clean oil resources, it is necessary to maintain octane numbers and reduce aromatics content of the gasoline products. As there are many primitive reactions involved in this system, the control of this reaction network via catalytic engineering is an important problem that must be faced [32]. The MIP technology developed by Sinopec would be a good solution for this problem. Based on the research of the carbenium ion in the acid catalytic network of the FCC reaction, it was found that the primitive steps such as carbon-carbon bonds cracking and carbon-chain transferring presented different dynamic effects at different temperatures with different catalyst contact times. Therefore, the two reaction zones of the MIP process were developed with one zone at high temperature and flow velocity, to increase the cracking rate, while the other at low temperature and flow velocity to selectively control the hydrogen transformation and isomerization, leading to the effective control of the product distribution and high alkane octane numbers, in industrial production [33].

Catalytic alkylation with ionic liquids

Alkylates are important components for cleaner oil products. They are made, with high octane numbers, by the alkylation reaction of the petrochemical by-products isobutane and butane [34]. To solve the problems of the traditional liquid-acid-catalyst system, such as the high acid-oil by-product, severe equipment corrosion, and difficult waste treatment, a composite ionic-liquid catalytic system was explored by Chunming Xu et al. of China University of Petroleum and a 100000 ton/year plant for alkylation of carbon compounds with ionic liquids was built and industrialized. Nowadays, a novel liquid-liquid cyclone reactor (LLCR) has been designed to enhance mixing and accelerate separation between the reaction products and the catalyst and several 200000-300000 ton/year industrial plants are under construction $[35,36]$.

\subsection{Green chemical-catalysis technology}

\section{Green technology for hexanolactam}

The green way for chemical reactions includes mainly the raw materials, the process, and the products. The core of these factors is the green atom economy which can be achieved via integrated new catalytic materials, new projects, and new reaction systems. In the hexanolactam refining process, a new catalytic material, amorphous Ni-alloy catalyst, was applied by Baoning Zong et al. of Sinopec, who pioneered in combining the stable magnetic bed and microfiltration membrane separation with the environmental-friendly new technology of gas-phase 
Beckmann rearrangement. This technology simplified the production process, reduced plant investment by $70 \%$ and production costs by $10 \%$, and increased the atom utilization from $60 \%$ to over $90 \%$. It has become the paradigm of the green chemical industry, and was awarded the national technology invention award in 2007 [37-39].

Reviewing these successful industrializations that pushed economic and social development, we can find that a significant economic and social demand is the important motivation for the catalytic revolution. The collaborative innovation is the foundation for major breakthroughs in the energy and petrochemical industries. The collaborative innovation of industry and academia [40] is the root for achieving the grand plan of catalysis. The exploration generation, research and development generation, transformation generation, and promotion of the whole life cycle of catalyst should be the law of discontinuous scientific and technological progress.

As pointed by Enze Min [41] the development of the catalytic technology belongs to the typical discontinuous scientific and technological progress, by which the new scientific knowledge and development should be built on the basis of the original ones. The above industrial achievements, especially the progress of the generation of catalytic technologies such as the MIP, are representatives of the discontinuous technological progress. The whole life cycle of a catalyst is shown in Fig. 2.

\section{The technological problems of the catalytic development in China}

\subsection{The reaction network and engineering research}

The research of catalytic systems would include the reaction network, the process-route selection, the catalytic-reaction engineering, etc. The system is generally complex and multi-dimensional. Multiple dynamic equilibriums are also involved. The catalysis allows the independent control of the reaction rate which is crucial for the effective integration of several reactions. Therefore, the catalytic research work should start from the primary reactions, and take into account the integrated catalytic system for the whole network rather than the single reaction $[42,43]$. This systematic study should also include the research from the atomic/molecular level of the reaction mechanisms to the macro-level of the catalytic engineering, and even the industrialization stage.

According to the statistics from the 17th National Catalysis Conference (Fig. 3), the hot research topics are mainly focused on catalytic material, reaction-mechanism characterization, and new reactions, while the articles related to the catalytic-reaction engineering only represented a $5 \%$ share. This result reflects, to some degree, the shortage of catalytic-engineering research. We should pay more attention to the systematic research and engineering study of catalysis, especially the study of catalytic-reaction engineering.

\subsection{The engineering for the fabrication of catalysts}

Due to the industrial-processes requirements of catalyst strength, pressure drop, and heat and mass transfer, the composition of industrial catalysts is more complicated and quite different from the model catalysts used in laboratory research. The spatial dimension (from the atomic nanometer scale to the reactor meter scale) and time dimension (from the picoseconds level of the catalytic process to the year level of the catalyst industrial use) cross several orders of magnitude, being a typical chemical engineering cross-scale problem (Fig. 4) [44], and must be fully considered in the catalyst design, fabrication, and

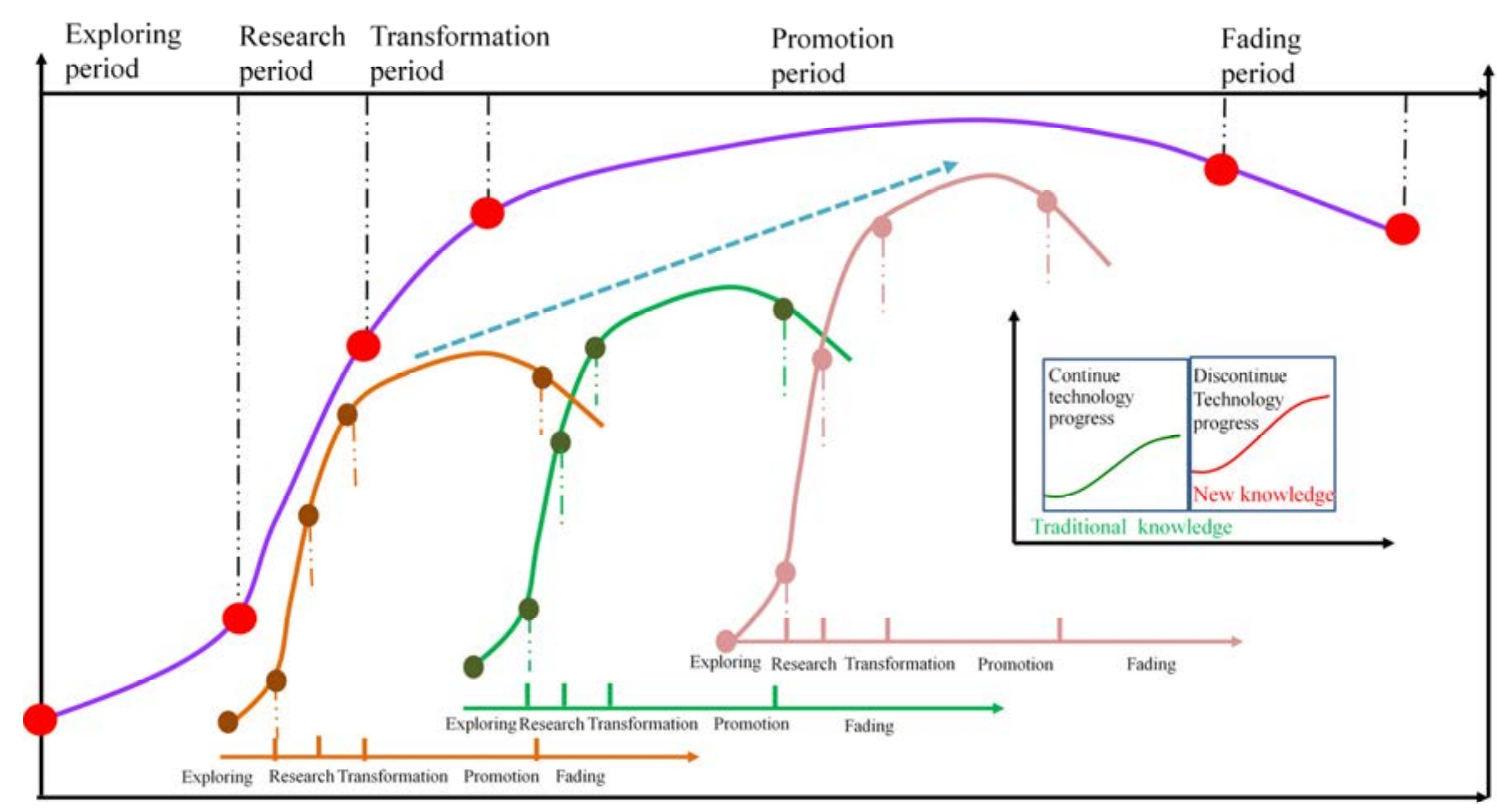

Investment

Fig. 2. Whole life cycle of catalyst and discontinuous technology progress, the discontinuous technology progress at the right inset is cited from Ref. [41]. 


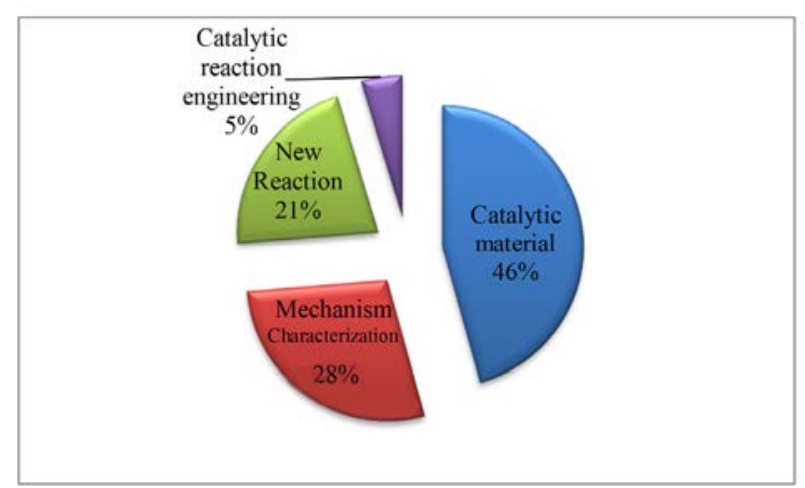

Fig. 3. The statistics analysis of the articles on different areas, in the 17 th National Catalysis Conference.

application. For example, the utilization efficiency of the active centers is a key parameter of industrial catalysts and, due to the influence of diffusion, the apparent activity of a catalyst is rarely equal to the chemical intrinsic activity of the catalytic material, i.e. the efficiency factor is less than $1[45,46]$. Thus, to increase the efficiency factor is definitely the target for designing and preparing industrial catalysts.

The ZSM-5 catalyst applied in the methanol to propylene (MTP) process was made to spherical or strip particles by adding an inert binder. It was found that in the catalyst with $30 \%$ binder added, the activity was reduced by $63 \%$, due to the blocked pores and the lowered diffusion in the binder [47].
How to obtain the apparent activity of the catalyst close to its intrinsic properties is a core problem for catalyst efficiency. One strategy is to develop a fully crystallized catalyst. Its main points rest on the transformation of a solid-phase amorphous binder into the same structure as a molecular sieve, which increases the number of active centers and their accessibility. However, during this transformation, the catalyst could easily present low efficiency and mechanical strength. Thereafter, Zaiku Xie et al. [48] synthesized a fully crystallized catalyst by separating the sol and the binder phase with a uniformly formed macroporous material thus improving the efficiency of the solid-phase crystal. From the Taylor modulus research, its catalytic activity was increased 2.6 times, being close to the molecular sieve intrinsic properties. Under industrial conditions, its stability in the MTP process (one-way cycle) is as long as $2000 \mathrm{~h}$, an incredible catalyst's life time [44].

\section{The discussion on the direction of catalytic development in China}

\subsection{Pay attention to the top design of catalytic development}

On July 25, 2016, the European Cluster on Catalysis published "Science and Technology Roadmap on Catalysis for Europe" [43]. This roadmap was prepared from a large number of references for catalysis from existing results and science and technology policies. It was oriented towards the catalytic tech-

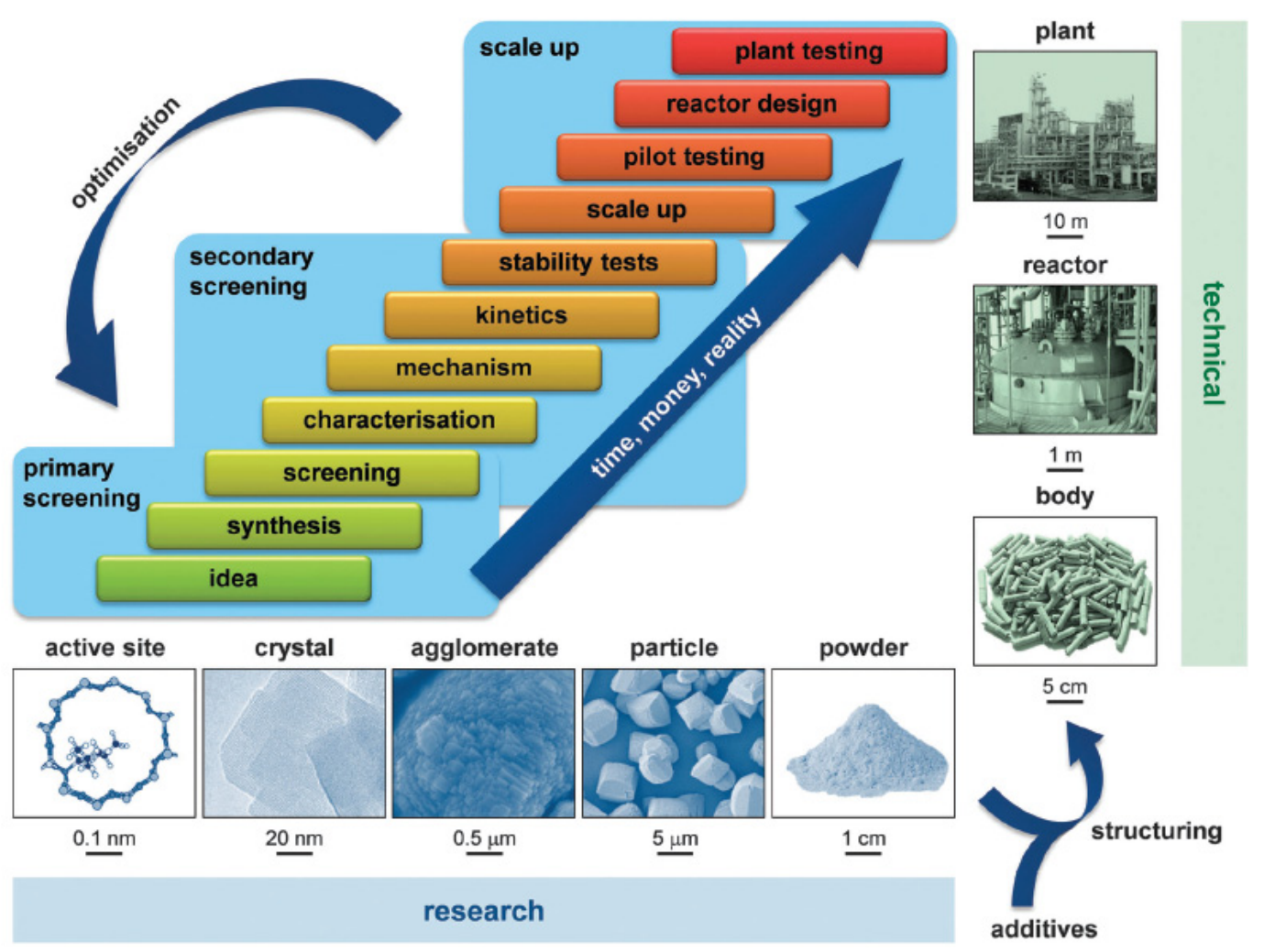

Fig. 4. Typical sequence of the interactive tasks followed in a catalyst development program. A key step is the translation of a promising research catalyst into a technical catalyst involving the extrapolation of laboratory recipes to an industrial scale and the structuring of powders with additives into millimeter-sized bodies. Successfully implemented technologies are those which deliver recognizable performance benefits upon bridging the multiple-length scales from the active site to the chemical plant [44]. 


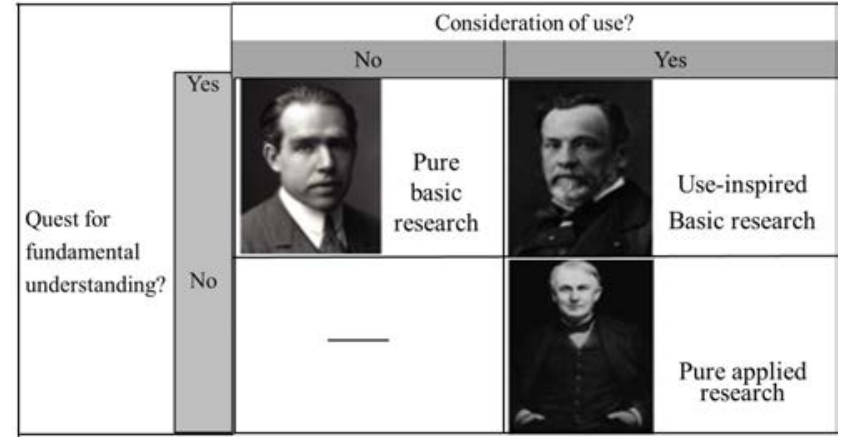

Fig. 5. Pasteur's Quadrant: Basic Science and Technological Innovation. Scientific research can be classified by whether it advances human knowledge by seeking a fundamental understanding of nature, or whether it is primarily motivated by the need to solve immediate problems [49].

nique efficiency and the sustainable development of the future European society, to ensure the world's leadership of Europe in the field of sustainable chemistry.

Three grand challenges were revealed in this roadmap and strategies with high-level goals for 10-20 years were also pointed out. The first challenge was for the catalysis to address the evolving energy and chemical scenario. The second challenge was the catalysis for a cleaner and sustainable future. And the last one was addressing the catalysis complexity.

This catalytic road map is highly targeted and deserves our consideration. The Chinese Zeolite Association in our country is drawing our catalytic roadmap now. It is important to pay attention to the coordination of the vital society demands with the basic research, as per Pasteur's Quadrant (Fig. 5) [49].

\subsection{Scientific problems in the direction of green development}

In recent years, a series of catalytic demands and scientific problems have been extracted on the topic forums, like the Xiangshan conference. Two scientific questions about catalytic efficiency are emphasized in this paper.

First, we should pay attention to the problem of catalytic efficiency and seek a comprehensive understanding of heterogeneous, homogeneous, and enzyme catalysis. Heterogeneous and homogeneous catalysis have their own advantages and disadvantages, making the selection difficult in industrial catalysis, and there is extensive ongoing research currently to overcome their limitations in different ways. The new concept of "grand catalysis" should integrate all of the heterogeneous, homogeneous or even the enzyme catalysis and promote the breakthrough of new technologies in catalysis [50].

The three domains of the "grand catalysis" theory (heterogeneous, homogeneous and enzyme catalysis) could be communicated with each other at the molecular level $[43,50]$. The basic structures of the three are influenced by the electric charge and the coordination environment. But there are also some differences in their homogeneity and the scale of their active centers. By regulating the catalytic components and molecules, a hybrid system of the three catalytic types could be established, leading to unique product selectivity for multi-paths multi-products reaction networks. Fig. 6 shows the evolution of catalyst complexity and catalytic selection [51].

The establishment of the above theoretical system of catalysis is its ultimate goal. At present, there are some very hot research topics, including single-atom catalysis, which are all

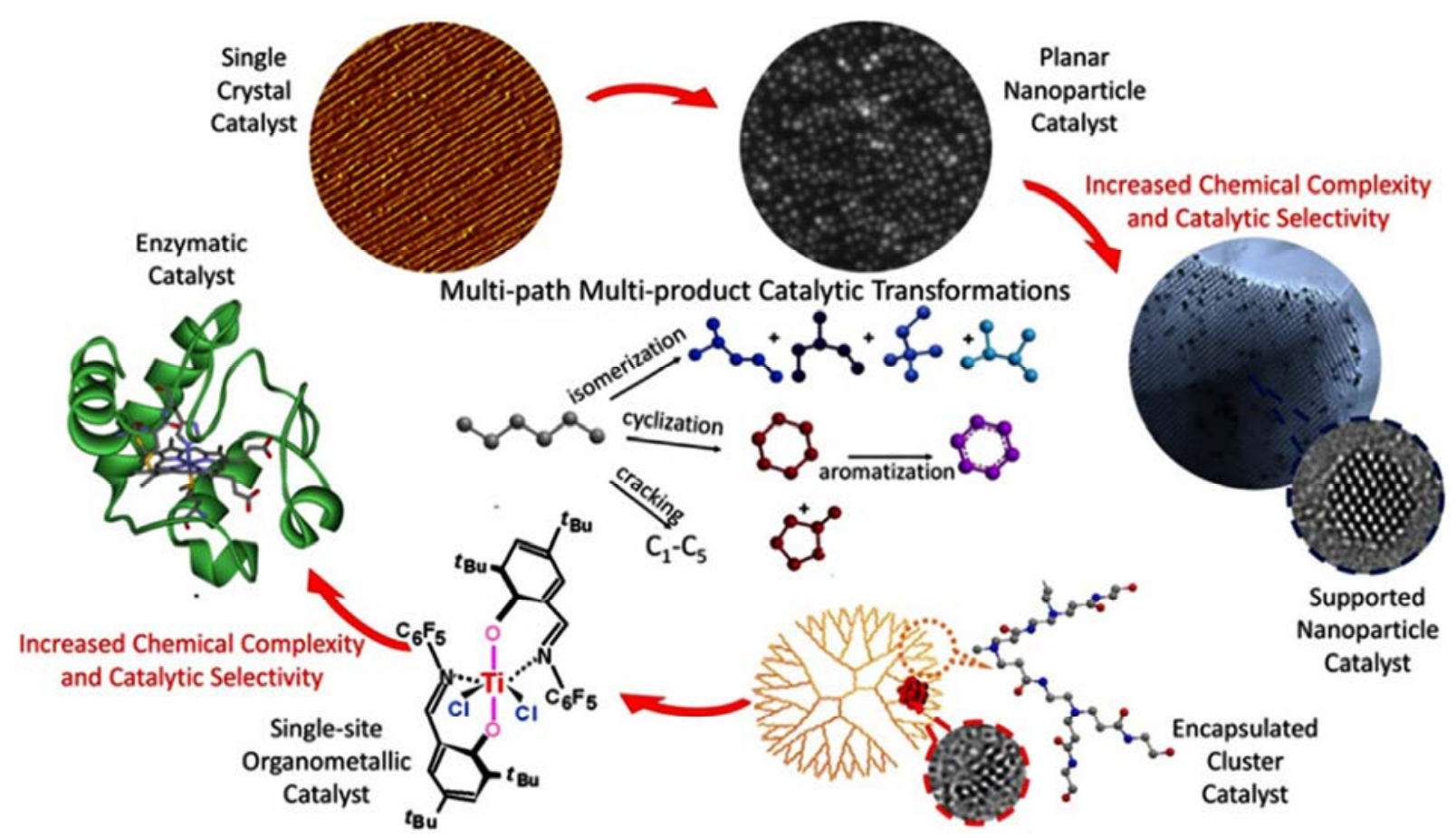

Fig. 6. Schematics showing the evolution of catalyst complexity leading to increased catalytic selectivity for multipath and multiproduct catalytic transformations [51]. 


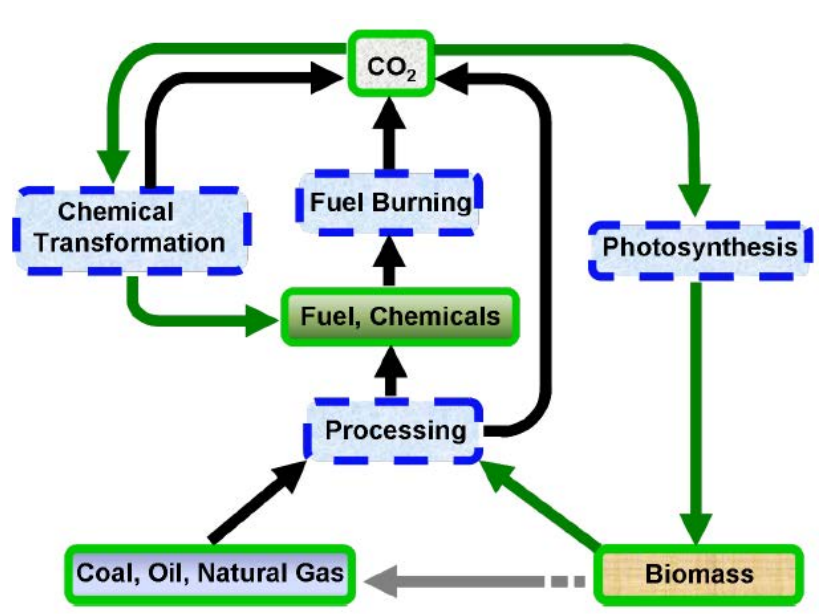

Fig. 7. The simplified carbon cycle and related processes [53].

considered to be very important breakthroughs. In this regard, the nano-sized reactor system, lying between homogeneous and heterogeneous catalysis, developed by Can Li and the new concept of single-atom catalysis explored by Tao Zhang have all made important contributions to the establishment of this theoretical system [52].

Second, the catalytic efficiency of the whole process of a multi-step catalytic system should be rigorously considered. According to the concept of carbon science (Fig. 7) developed by Mingyuan He et al. [53] in the catalytic technology of fossil-resource conversion, the attention should be focused on carbon processing, energy utilization of resources, carbon fixation, and even the whole process of the carbon cycle. For the purpose of the optimization of the carbon-atom economy and efficiency, stoichiometric reactions should be replaced by catalytic reactions with minimal steps, highest selectivity and minimal carbon emissions, rationally utilizing the limited carbon fossil fuels [54-56]. In the view of the hydrogen-science concept (Fig. 8), it is necessary to focus on the inefficient energy consumption and consumption of hydrogen, hydrogen storage and hydrogen utilization $[57,58]$.

It should be pointed out that the $\mathrm{CO}_{2}$ emissions come mainly from the traditional petrochemical-process. Fig. 9 presents the data corresponding to oxidation, cracking, hydrogenation and $\mathrm{C}-\mathrm{C}$ bond formation [59]. With the concept of green carbon science, scientists should take note of the catalytic materials

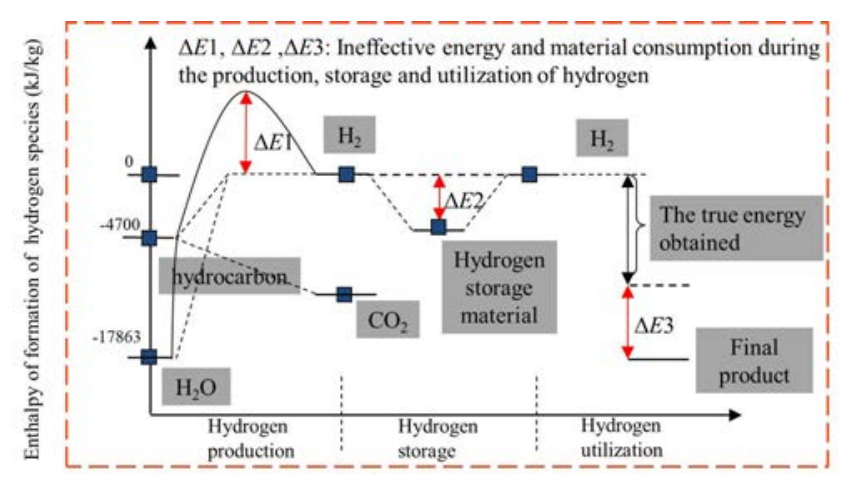

Fig. 8. Schematic illustration of the energy transformation within the hydrogen technology.

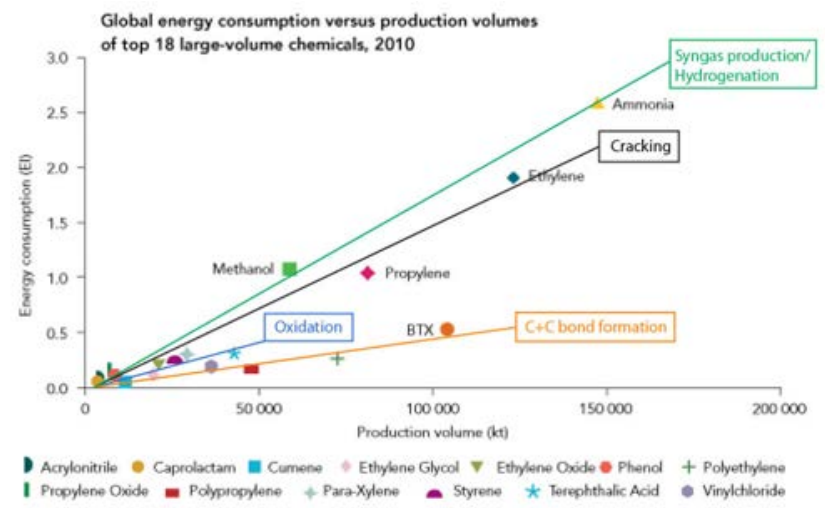

Fig. 9. Global energy consumption versus production volumes of top 18 large-volume chemicals in 2010 [59].

which we believe will be the breakthrough from the traditional petrochemical processes or even the new technologies.

\subsection{Establish a catalytic engineering base and alliance}

We should encourage researchers to efficiently carry out collaborative innovation and set up a number of significant catalytic subjects or alliances, promoting chain-style innovation.

As a result, the gap between basic study and applied research could be minimized via the cooperation of the academic and the industrial research teams, with creative concepts and engineering innovation integrated together. The academic and industrial scientists should take their own responsibilities, that is, the leading role in material, concepts, and fabrication aspects of the academic research should be continued in the future, while the application ability of the industrial team should be widely appreciated. There should be excellent communication between the academic scientists who would explore new areas to satisfy society's demands and the industrial scientists who should bravely push the plant, demonstration and industrialization. The common picture is to focus on the revolution of catalysis founded on the basis of major economic and social problems, and strengthen the bridge from fundamental to applied catalysis [44].

\section{Conclusions}

Catalysis is at the technological core of energy, chemical industry, materials, environment, medicine and much more. It plays an important role in promoting industrial revolution and social development. Catalysis is a typically comprehensive science involving chemistry, physics, biology, mathematics, materials, engineering, and other fields, lying at the intersection of basic and applied research and being closely related to green chemistry and sustainable development.

Catalysis in our country has made significant progress in the energy and chemical industries. In order to remain competitive and achieve sustainable development, catalysis could be chosen as a break point to ascend to the height of core technologies, for a sustainable future. Moreover, all sources should be employed 
to draw the roadmap. Focusing on the revolution of petrochemical catalysis and promoting collaborative innovation of academic and industrial research should be the main concern for furthering catalysis.

\section{References}

[1] H. Z. Liu, Chin. J. Catal., 2014, 35, 1619-1640.

[2] M. Y. He, Green Chemistry Related to Petroleum Refining and Petrochemical Production, China Petrochemical Press, Beijing, 2006, 1-10.

[3] L. A. Castonguay, A. K. Rappe, J. Am. Chem. Soc., 1992, 114, 5832-5842.

[4] M. Shelef, G. W. Graham, Catal. Rev. Sci. Eng., 1994, 36, 433-457.

[5] X. G. Guo, G. Z. Fang, G. Li, H. Ma, H. J. Fan, L. Yu, C. Ma, X. Wu, D. H. Deng, M. M. Wei, D. L. Tan, R. Si, S. Zhang, J. Q. Li, L. T. Sun, Z. C. Tang, X. L. Pan, X. H. Bao, Science, 2014, 344, 616-619.

[6] L. S. Zhong, F. Yu, Y. L. An, Y. H. Zhao, Y. H. Sun, Z. J. Li, T. J. Lin, Y. J. Lin, X. Z. Qi, Y. Y. Dai, L. Gu, J. S. Hu, S. F. Jin, Q. Shen, H. Wang, Nature, 2016, 538, 84-87.

[7] B. T. Qiao, A. Q. Wang, X. F. Yang, L. F. Allard, Z. Jiang, Y. T. Cui, J. Y. Liu, J. Li, T. Zhang, Nat. Chem., 2011, 3, 634-641.

[8] X. L. Yang, X. Su, X. D. Chen, H. M. Duan, B. L. Liang, Q. G. Liu, X. Y. Liu, Y. J. Ren, Y. Q. Huang, T. Zhang, Appl. Catal. B, 2017, 216, 95-105.
[9] J. Z. Li, Y. X. Wei, G. Y. Liu, Y. Qi, P. Tian, B. Li, Y. L. He, Z. M. Liu, Catal. Today, 2011, 171, 221-228.

[10] Z. B. Shi, P. Ji, Z. G. Zhu, J. G. Jiang, W. H. Fu, P. Wu, Y. M. Wang, M. Y. He, ChemCatChem, 2016, 8, 1891-1895.

[11] P. Lanzafame, S. Perathoner, S. G. G. Centi, E. J. M. Hensen, Catal. Sci. Technol, 2017, 7, 5182-5194.

[12] G. J. Hutchings, J. Mater. Chem., 2009, 19, 1222-1235

[13] P. Tian, Y. X. Wei, M. Ye, Z. M. Liu, ACS Catal., 2015, 5, 1922-1938.

[14] H. X. Ma, F. Zhou, K. Qiao, Chemical Industry and Engineering Process, 2014, 33, 32-40.

[15] Z. Liu, C. Sun, G. Wang, Q. Wang, G. Cai, Fuel Processing Technol,, 2000, 62, 161-172.

[16] X. Liu, S. Ren, G. F. Zeng, G. J. Liu, P. Wu, G. Wang, X. Q. Chen, Z. Y. Liu, Y. H. Sun, RSC Adv., 2016, 6, 28787-28791.

[17] Z. M. Liu, Y. Qi, Achievements \& Projects, 2006, 21, 406-408.

[18] D. L. Cai, Q. Wang, Z. Jia, Y. H. Ma, Y. Cui, U. Muhammad, Y. Wang, W. Z. Qian, F. Wei, Catal. Sci. Technol, 2016, 6, 1297-1301.

[19] D. Rojo-Gama, S. Etemadi, E. Kirby, K. P. Lillerud, P. Beato, S. Svellea , U. Olsbye, Faraday Discussions, 2017, 197, 421-446.

[20] S. C. Baek, Y. J. Lee, K. W. Jun, S. B. Hong, Energy Fuels, 2009, 23, 593-598.

[21] L. Qi, J. Z. Li, L. Y. Wang, L. Xu, Z. M. Liu, Catal. Sci. Technol,, 2017, 7, 894-901.

[22] X. Q. Wu, S. T. Xu, W. N. Zhang, J. P. Huang, J. Z. Li, B. W. Yu, Y. X. Wei, Z. M. Liu, Angew. Chem. Int. Ed., 2017, 56, 9039-9043.

\section{Graphical Abstract}

Chin. J. Catal., 2018, 39: 1147-1156 doi: 10.1016/S1872-2067(18)63051-7

\section{Focus on the Chinese revolution of catalysis based on catalytic solutions for the vital demands of society and economy}

Yangdong Wang, Jing Shi, Zhonghao Jin, Zaiku Xie*

SINOPEC Shanghai Research Institute of Petrochemical Technology; China Petroleum \& Chemical Corporation

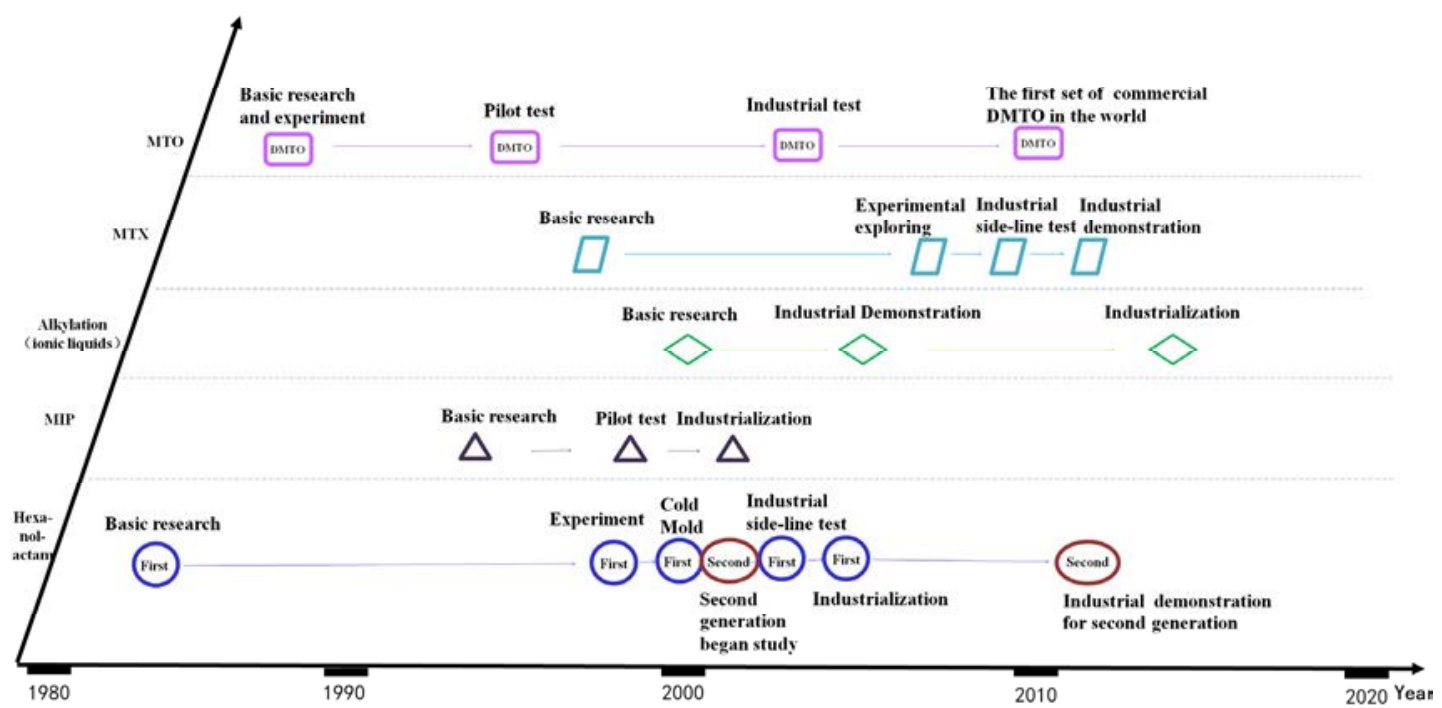

The milestones of China's significant industrial catalysis were summarized, and a discussion on the direction and strategy of catalysis, based on economic and social demands, was presented. Focusing on the revolution of catalysis and promoting collaborative innovation between academic and industrial research should be the main concerns for furthering catalysis. 
[23] Y. D. Wang, C. M. Wang, H. X. Liu, Z. K. Xie, Chin. J. Catal., 2010, 31, 33-37.

[24] H. X. Liu, Z. K. Xie, C. F. Zhang, Q. L. Chen, Chin. J. Catal., 2003, 24, 279-283.

[25] H. X. Liu, Z. K. Xie, X. Lu, W. Wang, K. Qian, Y. X. Zhang, CN101284246A, 2008.

[26] P. Lu, Z. Y. Fei, L. Li, X. Z. Feng, W. J. Ji , W. P. Ding, Y. Chen, W. M. Yang, Z. K. Xie, Appl. Catal. A, 2013, 453, 302-309.

[27] T. Yashima, K. Yashima, H. Ahmad, M. Katsuta, H. Nobuyoshi, J. Catal., 1970, 17, 151-156.

[28] R. Mantha, S. Bhatia, M. S. Rao, Ind. Eng. Chem. Res., 1991, 30, 281-286.

[29] J. Zhou, Y. D. Wang, W. Zou, C. M. Wang, L. Y. Li, Z. C. Liu, A. M. Zheng, D. J. Kong, W. M. Yang, Z. K. Xie, Ind. Eng. Chem. Res., 2017, 56, 9310-9321.

[30] H. L. Dai, Technology of Aromatic Hydrocarbon, China Petrochemical Press, Beijing, 2014, 577-582.

[31] Y. J. Liu, J. Long, H. P. Tian, Y. Xu, L. Z. Zhao, China Petroleum Processing and Petrochemical Technology, 2011, 13, 1-5.

[32] E. T. C. Vogt, B. M. Weckhuysen, Chem. Soc. Rev., 2015, 44, 7342-7370.

[33] J. H. Gong, Y. H. Xu , C. G. Xie, J. Long, W. B. Jiang , Z. Z. Qiu, China Petroleum Processing and Petrochemical Technology, 2009, 2, 1-8.

[34] Y. Liu, R. S. Hua, C. M. Xu, H. Q. Sua, Appl. Catal. A, 2008, 346, 189-193.

[35] Z. C. Liu, R. Zhang, Y. Liu, C. M. Xu, J. FuelChem. Technol., 2006, 34, 328-331.

[36] M. Y. Zhang, L. Y. Zhu, Z. B. Wang, Z. C. Liu, Z. Z. Liu, C. M. Xu, Y. H. Jin, Chem. Eng. Res. Desi., 2017, 125, 282-290.

[37] X. X. Zhang, B. N. Zong, M. Y. He, Sci. Sin. Chim., 2014, 44, 1-5.

[38] B. Sun, S. B. Cheng, X. K. Meng, K. Y. Yang, W. Wu, B. Zong, Sci. Sin. Chim., 2014, 44, 40-45.

[39] M. Y. He, Chin. J. Catal., 2014, 34, 10-21.

[40] Z. K. Xie, Z. C. Liu, Y. D. Wang, Sci. Sin. Chim., 2014, 44, 1394-1403.

[41] E. Z. Min, Chem. Eng. Oil Gas, 2011, 40, 1-6.

[42] J. Shi, Y. D. Wang, W. M. Yang, Y. Tang, Z. K. Xie, Chem. Soc. Rev.,
2015, 44, 8877-8903.

[43] S. Perathone, G. Centi, S. Gross, E. J. M. Hensen, European Cluster on Catalysis, 2016, 1-116.

[44] S. Mitchell, N. L. Michels, J. Perez-Ramirez, Chem. Soc. Rev., 2013, 42, 6094-6112.

[45] J. Perez-Ramirez, C. H.Christensen, K. Egeblad, C. H. Christensen, J. C. Groen, Chem. Soc. Rev., 2008, 37, 2530-2542.

[46] J. Zhou, Z. C. Liu Y, Y. D. Wang, H. X. Gao, L. Y. Li, W. M. Yang, Z. K. Xie, Y. Tang, RSC Adv., 2014, 4, 43752-43755.

[47] J. W. Teng, Z. K. Xie, Sci. Sin. Chim., 2015, 45, 533-540.

[48] J. Zhou, J. W. Teng, L. P. Ren, Y. D. Wang, Z. C. Liu, W. Liu, W. M. Yang, Z. K. Xie, J. Catal., 2016, 340, 166-176.

[49] D. E. Stokes, Pasteur's Quadrant: Basic Science and Technological Innovation, Brookings Institution Press, Washington, D. C., 1997.

[50] Y. Wu, Basis of Applied Catalysis, Chemical Industrial Press, Beijing, 2008, 150-152.

[51] R. Ye, T. J. Hurlburt, K. Sabyrov, S. Alayoglu, G. A. Somorjai, Proc. Natl. Acad. Sci. USA, 2016, 113, 5159-5166.

[52] B. Li, S. Y. Bai, X. F. Wang, M. M. Zhong, Q. H. Yang, C. Li, Angew. Chem. Int. Ed., 2012, 51, 11517-11521.

[53] M. Y. He, Y. H. Sun, B. X. Han, Angew. Chem. Int. Ed., 2013, 52, 9620-9633.

[54] G. A. Olah, G. K. S. Prakash, A. Goeppert, J. Am. Chem. Soc., 2011, 133, 12881-128989.

[55] Q. Yi, W. Y. Li, J. Feng, K. C. Xie, Chem. Soc. Rev., 2015, 44, 5409-5445.

[56] M. Y. He, Y. H. Sun, Sci. Sin. Chim., 2011, 41, 925-932.

[57] Z. K. Xie, Z. H. Jin, Y. D. Wang, Sci. Sin. Chim., 2013, 43, 930-938.

[58] T. Setoyama, T. Takewaki, K. Domen, T. Tatsumi, Faraday Discuss. 2017, 198, 509-527.

[59] J. Alper, The Changing Landscape of Hydrocarbon Feedstocks for Chemical Production: Implications for Catalysis: Proceedings of a Workshop, National Academies Press, Washington, D. C., 2016, 60-63.

\title{
聚焦变革中的催化一一始终基于解决重大经济社会需求的催化工程问题
}

\author{
王仰东 ${ }^{\mathrm{a}}$, 史 静 ${ }^{\mathrm{a}}$, 金中豪 ${ }^{\mathrm{a}}$, 谢在库 ${ }^{\mathrm{b}, *}$ \\ a中国石化上海石油化工研究院绿色化工与工业催化国家重点实验室, 上海201208 \\ b中国石油化工股份有限公司, 北京100027
}

摘要: 催化是化学工业中最重要和最普遍的跨学科技术, 也是具有重要社会影响的学科之一, 是一门基于应用、注重实践、 与化学工程息息相关的学科. 应用、实践是催化的根本, 也是其生命力所在, 其发展轨迹与人类的历史进程密不可分. 从 20 世纪初 Mittasch 贡献的高效 Fe 基催化剂为氮基化肥的大规模推广奠定了基础, 到 60 年代, 分子篮裂化催化剂使汽油 收率和辛烷值大幅提升, 为交通运输业的大力发展奠定了能源基础, 推动了交通运输业的革命. 从齐格勒和纳塔 $\mathrm{TiCl}_{4}-\mathrm{AlEt}_{3}$ 体系催化乙烯、丙烯、丁烯等在低压下高收率地聚合, 生成分子结构高度规整的立体定向聚合物——聚烯烃, 到 汽车排气管中的 Pt-Rh-Pd 三效催化剂, 可以通过氧化和还原反应, 把废气中的烃类物质和 $\mathrm{CO}$ 转化为水和 $\mathrm{CO}_{2}$, 同时把环 境危害大的 $\mathrm{NO}_{x}$ 分解成无害的 $\mathrm{N}_{2}$ 和 $\mathrm{O}_{2}$, 等等. 这些催化的印记推动了产业变革和社会进步. 可以说, 无处不在的催化支 撑了人类社会的发展. 近年有些突破也发生在我国, 使我们更加感受到催化的力量.

催化科学与技术是极其复杂的. 一方面表现在表面科学的知识和催化反应的物理化学现象建模, 材料科学和无机化 学以制备合适的纳米结构催化剂; 另一方面表现在催化剂成型、反应动力学评价和催化过程建模. 这两个方面均涉及原料 多样性、催化材料多变性、化工工艺适应性、宏量制备放大效应, 以及本征与表观性能关联等复杂问题. 但是这些复杂性 问题与催化发展的根本相比, 或者说, 与催化发展的核心驱动力相比, 很显然, 催化解决重大经济社会问题更应引起关注, 这是催化的使命所在. 
目前, 我国催化基础研究走在了世界前列, 已经取得了重大突破, 李灿等成功组织举办了第16 届国际催化大会, 包信 和、孙予罕等科学家的一系列重大催化基础研究成果在 Science、Nature 等期刊上发表, 李灿、包信和等多名科学家被国 际催化相关学术组织颁发荣誉称号, 张涛等人一系列重大成果被评为重要进展. 与此同时, 我国在煤制烃、油品质量升级 以及绿色化工等能源化工催化方面取得了重大的工业化成果. 这些走在世界前列的重大催化工业化成果驱动了我国经济 社会发展.

本文试图总结这些重大工业化催化成果, 并基于经济社会发展提炼相关催化问题, 探讨发展方向、路径与对策. 关键词: 催化; 工业化; 制烃; 绿色化工; 催化发展

收稿日期: 2018-01-31. 接受日期: 2018-02-22. 出版日期: 2018-07-05.

*通讯联系人. 电话: (021)68462947; 传真: (021)68462283; 电子信箱: xzk@sinopec.com

基金来源：国家重点基础研究发展计划 (2013CB934101, 2009CB623500); 国家自然科学基金 (21433002, 21573046); 国家重点研 发计划项目 (2016YFB0701100).

本文的电子版全文由Elsevier出版社在ScienceDirect上出版(http://www.sciencedirect.com/science/journal/18722067). 